\title{
Developmental Regulation of the cm2 Muscarinic Acetylcholine Receptor Gene: Selective Induction by a Secreted Factor Produced by Embryonic Chick Retinal Cells
}

\author{
Lise A. McKinnon, ${ }^{1}$ Erik C. Gunther, ${ }^{2}$ and Neil M. Nathanson ${ }^{1}$ \\ 1 Department of Pharmacology, University of Washington School of Medicine, Seattle, Washington, 98195-7750, and \\ 2Department of Physiology and Biophysics, Molecular and Cellular Biology Program, University of Washington School of \\ Medicine, Seattle, Washington, 98195-7290
}

\begin{abstract}
The expression of the $\mathrm{cm} 2$ muscarinic acetylcholine receptor gene increases dramatically in chick retina during embryonic development in vivo. A similar developmental increase in $\mathrm{cm} 2$ expression occurs in embryonic chick retinal cells in culture. Conditioned medium from mature, but not young, retinal cultures contains a secreted factor that causes a selective increase in expression of $\mathrm{cm} 2$, but not $\mathrm{cm} 3$ or $\mathrm{cm} 4$, receptors. The secreted factor has been partially purified from serum-free medium, is protease-sensitive, and has a molecular weight $>10$ $\mathrm{kDa}$. The $\mathrm{cm} 2$-inducing factor stimulates expression of a $\mathrm{cm} 2$
\end{abstract}

promoter/luciferase reporter gene, demonstrating that the increase in $\mathrm{cm} 2$ expression is attributable to increased gene transcription. Incubation of retinal cells with 14 identified neurotrophic and growth factors did not increase $\mathrm{cm} 2$ expression, suggesting that a novel developmentally regulated secreted factor mediates the subtype-specific induction of the $\mathrm{cm} 2$ receptor gene in retina.

Key words: gene regulation; mAChR; retina; embryonic development; subtype selectivity; secreted factor
Muscarinic acetylcholine receptors (mAChR) are transmembrane receptor proteins belonging to a superfamily of receptors that couple to GTP-binding proteins (G-proteins) to elicit cellular responses on agonist stimulation of the receptor (for review, see Nathanson, 1987; Wess, 1996). mAChR are believed to modulate the processing of visual information in the neural retina. In frog retina it has been suggested that $\mathrm{mAChR}$ on glycinergic amacrine cells may have a role in a cholinergic/glycinergic-amacrine cell loop that is responsible for the inhibition of the OFF channel pathway by the ON channel pathway (Bonaventure et al., 1989; Jardon et al., 1992). In the salamander retina mAChR modulate both the input and output of amacrine, bipolar, ganglion, and horizontal cells because of the close proximity of pre- and postsynaptic specializations (Townes-Anderson and Vogt, 1989).

Affinity alkylation and SDS gel electrophoresis demonstrated that the predominant form of $\mathrm{mAChR}$ in chick retina early in embryonic development had an apparent molecular weight of 86 $\mathrm{kDa}$, whereas later in development a $72 \mathrm{kDa}$ form became predominant (Large et al., 1985). A similar shift in apparent molecular weight also occurred in retinal cell culture (Skorupa and Klein, 1993). Treatment of young retinal cultures with conditioned medium collected from mature retinal cultures causes the switch in expression levels of each species to occur sooner than in control cultures. This suggests that the mature retinal cells secrete

Received April 28, 1997; revised Oct. 9, 1997; accepted Oct. 14, 1997.

This work was supported by National Institutes of Health Grants NS26920 and HL30639 to N.M.N, training Grant GMO7750 to L.A.M., and training Grant GMO7270 to E.C.G. We thank Dr. Virginia Lee for the anti-neurofilament antibody, Dr. John Saari for the anti-IRBP antibody, Dr. Rae Nishi for the GPA, Cambridge Neuroscience for the neuregulin, Genentech for the GDNF, Dr. Randall T. Moon for the FGF and BO-PRO-3 iodide, Dr. Edwin G. Krebs for the PDGF, and Dr. Thomas Reh for helpful scientific discussions.

Correspondence should be addressed to Dr. Neil M. Nathanson, Department of Pharmacology, Box 357750, University of Washington, Seattle, WA 98195-7750.

Copyright (C) 1997 Society for Neuroscience $0270-6474 / 97 / 180059-11 \$ 05.00 / 0$ a factor involved in regulating the expression of the $72 \mathrm{kDa}$ species. Skorupa and Klein (1993) hypothesized that mature retinal cells secrete a factor that causes a change in transcription of genes encoding mAChR of different sizes. However, these data do not rule out the possibility of post-translational modification of the $86 \mathrm{kDa}$ protein, because the molecular identities of the 72 and $86 \mathrm{kDa}$ species were unknown.

We have shown by immunoprecipitation and solution hybridization that the $\mathrm{cm} 2, \mathrm{~cm} 3$, and $\mathrm{cm} 4$ receptors are expressed in embryonic chick retina (McKinnon and Nathanson, 1995). cm4 is the predominant receptor subtype expressed in embryonic chick retina, and the levels of both $\mathrm{cm} 4$ protein and mRNA decrease as development proceeds. The levels of $\mathrm{cm} 2$ and $\mathrm{cm} 3$ protein and mRNA expression are very low early in development. Both proteins steadily increase in expression during development, whereas the mRNA levels peak at E15. By immunoblot analysis we have identified the $72 \mathrm{kDa}$ protein as $\mathrm{cm} 2$; the $86 \mathrm{kDa}$ form consists of both $\mathrm{cm} 3$ and $\mathrm{cm} 4$ (McKinnon and Nathanson, 1995).

We have used subtype-specific riboprobes and antibodies to study the effects of conditioned medium on the expression of $\mathrm{cm} 2$, $\mathrm{cm} 3$, and $\mathrm{cm} 4$ mRNA and protein in primary embryonic chick retinal cultures. We have found that cultured retinal cells secrete a developmentally regulated protease-sensitive factor that induces a selective increase in $\mathrm{cm} 2 \mathrm{mRNA}$ and protein expression. We have used the recently cloned $\mathrm{cm} 2$ promoter (Rosoff et al., 1996) to show that this increase in $\mathrm{cm} 2$ mRNA is attributable to stimulation of transcription of the $\mathrm{cm} 2$ gene.

\section{MATERIALS AND METHODS}

Preparation of primary retinal cultures. Fertilized eggs from white Leghorn chickens (H\&N International, Redmond, WA) were incubated in a humidified environment at $38^{\circ} \mathrm{C}$ until the eighth or ninth day of incubation. Retina were dissected free of pigmented epithelium and dissociated as described by Reh (1992). Retina were trypsinized in $0.25 \%$ trypsin (Worthington Biochemical, Freehold, NJ) in HBSS, $\mathrm{Ca}^{2+}-$ and $\mathrm{Mg}^{2+}$ - 
free (Life Technologies, Grand Island, NY), for $15 \mathrm{~min}$ at room temperature. The trypsin was inactivated by the addition of fetal bovine serum (FBS; Life Technologies) to a final concentration of $20 \%$. Retinal cells were centrifuged at $1000 \mathrm{rpm}$ for $8 \mathrm{~min}$ and triturated in DMEM/F12 medium (Life Technologies) containing 10\% FBS, 1\% penicillin/streptomycin (Life Technologies), $330 \mathrm{~mm}$ glucose, and 5 mM HEPES, pH 7.4. Serum-free medium (modified from de la Rosa et al., 1994) consisted of DMEM/F12 supplemented with $1 \%$ penicillin/streptomycin, $330 \mathrm{~mm}$ glucose, $5 \mathrm{~mm}$ HEPES, pH 7.4, $100 \mu \mathrm{g} / \mathrm{ml}$ transferrin, $6 \mathrm{ng} / \mathrm{ml}$ putrescine, $5.2 \mathrm{ng} / \mathrm{ml}$ sodium selenite, and $6 \mathrm{ng} / \mathrm{ml}$ progesterone (Sigma, St. Louis, $\mathrm{MO})$. Cells dissociated from E9 retina were plated on $150 \mathrm{~mm}$ plates coated with poly-D-lysine $(0.1 \mathrm{mg} / \mathrm{ml} ; 30,000-70,000$ molecular weight; Sigma) at a density of $4-5 \times 10^{7}$ cells per plate. Cells dissociated from E8 retina were plated on 24-well plates coated with poly-D-lysine at a density of $2-2.5 \times 10^{6}$ cells per well. Cultures were incubated in a $5 \%$ $\mathrm{CO}_{2}$ environment. The day of plating was considered to be culture day zero. Conditioned medium was collected from the E9 cultures every 24 hr, beginning on culture day 5 and continuing through culture day 8 , and stored at $-20^{\circ} \mathrm{C}$.

Culture of stable cell lines and a transiently transfected cell line. The Y1 mouse adrenal carcinoma cell lines stably expressing $\mathrm{cm} 2$ (Tietje and Nathanson, 1991) or cm4 (Tietje et al., 1990) were grown in F-10 medium (Life Technologies) supplemented with $15 \%$ FBS, $1 \%$ penicillin/streptomycin, and $500 \mu \mathrm{g} / \mathrm{ml} \mathrm{G} 418$ (Life Technologies) in a $5 \% \mathrm{CO}_{2}$ environment. COS-7 green monkey kidney cells were grown in DMEM (Life Technologies) supplemented with $10 \%$ FBS and $1 \%$ penicillin/streptomycin in a $10 \% \mathrm{CO}_{2}$ environment. COS-7 cells plated on $150 \mathrm{~mm}$ culture dishes were transiently transfected with $50 \mu \mathrm{g}$ of $\mathrm{cm} 3$ in $\mathrm{pED}$ by the calcium phosphate precipitation method (Sambrook et al., 1989).

Immunocytochemistry on cultured cells. Retinal cultures were prepared from E9 retina as described above and plated on glass slides coated with poly-D-lysine. On the fifth day of culture, cells were fixed with $4 \%$ paraformaldehyde and $4 \%$ sucrose in PBS, $\mathrm{pH} 7.4$. Y1 cm2 cells, COS-7 $\mathrm{cm} 3$ cells, and $\mathrm{Y} 1 \mathrm{~cm} 4$ cells also were grown on glass slides coated with poly-D-lysine and fixed for immunocytochemistry. After fixation, cells were permeabilized in $0.25 \%$ Triton X-100 and then blocked for at least $2 \mathrm{hr}$ at room temperature with $10 \%$ bovine serum albumin (BSA) in PBST (PBS and $0.1 \%$ Tween 20). Primary antibodies were diluted in 3\% BSA in PBST and incubated on the slides overnight at $4^{\circ} \mathrm{C}$ in a humidified chamber. Secondary antibodies were diluted in 3\% BSA in PBST and incubated on the slides for at least $2 \mathrm{hr}$ at room temperature in a humidified chamber. Then slides were coverslipped with Vectashield (Vector Laboratories, Burlingame, CA) and stored at $4^{\circ} \mathrm{C}$. Slides were photographed at $400 \times$ magnification with Kodak (Rochester, NY) Elite II 400 ASA film. The dilutions used for the primary antibodies were anti-cm2, 1:200; anti-cm3, 1:1000; and anti-cm4, 1:500. Antineurofilament antibody, RMO 270, a gift from Dr. Virginia Lee (University of Pennsylvania), was used at 1:500; anti-neurofilament was used to label ganglion cells (Bradshaw et al., 1995). Anti-IRBP, F7, a gift from Dr. John Saari (University of Washington), was used at a dilution of 1:1000; anti-IRBP was used to label photoreceptors (Sheedlo and Turner, 1996). Anti-vimentin (H5), anti-Islet-1 (39.4D5), and antitenascin (M1-B4) monoclonal antibodies were used at 1:10, 1:100, and 1:500, respectively, and were purchased from the Developmental Studies Hybridoma Bank maintained by the Department of Pharmacology and Molecular Sciences, Johns Hopkins University School of Medicine (Baltimore, MD) and the Department of Biological Sciences, University of Iowa (Iowa City, IA) under contract N01-HD-6-2915 from the National Institute of Child Health and Human Development. Anti-vimentin was used to label Müller glia (Chabot and Vincent, 1990; Willbold et al., 1995), anti-Islet-1 to label ganglion cells (Thor et al., 1991), and antitenascin to label amacrine and horizontal cells (Bartsch et al., 1995). Anti-protein kinase $\mathrm{C}$ ( $\alpha$ and $\beta$ forms) RPN536 (Amersham Life Science, Arlington Heights, IL) was used at a dilution of 1:500; anti-PKC ( $\alpha$ and $\beta$ ) labels a subset of bipolar cells in chick retina (Hamassaki-Britto et al., 1994). Fluorescein-conjugated anti-rabbit IgG and rhodamineconjugated anti-mouse IgG secondary antibodies were purchased from Cappel Research Products (Durham, NC). The nuclear stain BO-PRO-3 iodide (Molecular Probes, Eugene, OR), a gift from Dr. Randall T. Moon (University of Washington), was used at a dilution of 1:5000.

Immunocytochemistry on embryonic chick retinal slices. Eyes from E14 chicks (vitreous humor removed) were fixed in $4 \%$ paraformaldehyde at room temperature for $45 \mathrm{~min}$. After fixation the eyes were cryoprotected in $30 \%$ sucrose in PBS at room temperature for $5 \mathrm{hr}$, embedded in O.C.T. (Miles, Elkhart, IN), and frozen in liquid nitrogen. Sections of $20 \mu \mathrm{m}$ each were collected on gel-coated slides and ringed with rubber cement. The slides were incubated in blocking buffer (PBS plus 0.3\% Triton $\mathrm{X}-100$ and 5\% donor goat serum) at room temperature for $1 \mathrm{hr}$. Primary antibodies (anti-cm2, 1:200; anti-cm3, 1:1000; anti-cm4, 1:500) were diluted in blocking buffer and incubated on the slides for $48 \mathrm{hr}$ in a humidified chamber at room temperature. After being washed with PBS, the slides were incubated with biotinylated goat anti-rabbit antibody (1:500, Vector Laboratories) diluted in blocking buffer for $2 \mathrm{hr}$ at room temperature, followed by FITC-ExtrAvidin (1:50; Sigma) diluted in blocking buffer for $2 \mathrm{hr}$ at room temperature. The slides were washed extensively with PBS and then coverslipped with Vectashield and visualized with a Bio-Rad (Richmond, CA) MRC 600 confocal microscope at $60 \times$ magnification.

Immunoprecipitation assay. Cultured retinal cells prepared from E9 retina were washed twice with ice-cold PBS, pH 7.4, harvested in $50 \mathrm{~mm}$

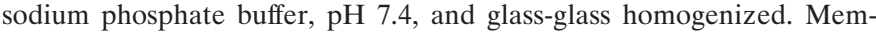
branes were recovered from the disrupted cells by centrifugation and used for the immunoprecipitation assay (McKinnon and Nathanson, 1995). Anti-mAChR antibodies were used at a 1:100 dilution for the assay.

Solution hybridization assay. Cultured retinal cells prepared from E9 retina were washed twice with ice-cold PBS, pH 7.4; RNA was isolated, using the method of Peppel and Baglioni (1990). Molecules of mAChR mRNA present in 10-20 $\mu \mathrm{g}$ of total RNA were quantitated by using subtype-specific riboprobes in the solution hybridization assay as previously described (Habecker and Nathanson, 1992; McKinnon and Nathanson, 1995).

Column chromatography. Serum-free conditioned medium (SFCM) was concentrated 10 -fold at $4^{\circ} \mathrm{C}$ with an Amicon Ultrafiltration Cell, using a PM10 Diaflo Ultrafilter (Amicon, Beverly, MA). Concentrated SFCM was aliquotted and stored at $-20^{\circ} \mathrm{C}$. The concentrated SFCM $(10$ $\mathrm{ml}$ ) was dialyzed overnight in $20 \mathrm{~mm}$ HEPES and $10 \mathrm{~mm} \mathrm{NaCl}, \mathrm{pH} 7.4$, at $4^{\circ} \mathrm{C}$. The dialyzed SFCM was passed over a DEAE Sephacel (Pharmacia, Piscataway, NJ) minicolumn with a bed volume of $2 \mathrm{ml}$. The flow-through was collected, dialyzed overnight at $4^{\circ} \mathrm{C}$ in PBS, pH 7.4, and stored at $-20^{\circ} \mathrm{C}$ until use. In some cases, for the transfection experiments, the DEAE flow-through (DEAE FT) was passed over a DEAE column a second time for complete removal of transferrin, the sole protein component of the serum-free medium.

Protease treatment of DEAE column flow-through. Pronase and proteinase $\mathrm{K}$ were purchased from Sigma as insoluble enzymes on agarose beads. DEAE FT was incubated with Pronase $(2 \mathrm{mg} / \mathrm{ml})$ or proteinase K $(40 \mathrm{mg} / \mathrm{ml})$ agarose beads for $2 \mathrm{hr}$ at $37^{\circ} \mathrm{C}$ in a rotating incubator. The insoluble enzymes were removed by centrifugation. Digested DEAE FT was stored at $-20^{\circ} \mathrm{C}$ until use.

Preparation of crude soluble protein extracts from embryonic chick tissues. Crude soluble protein extracts were prepared from E12 retina, E12-E15 ventricle, and E15 brain. The tissues were glass glasshomogenized in $2 \mathrm{vol} /$ wet weight $(\mathrm{ml} / \mathrm{gm})$ in PBS, $\mathrm{pH} 7.4$, containing 0.4 mM phenylmethanesulfonyl fluoride and $1 \mu \mathrm{M}$ pepstatin A. The homogenized samples were centrif uged at $5000 \mathrm{rpm}$ in a Beckman JA-20 rotor for $10 \mathrm{~min}$ at $4^{\circ} \mathrm{C}$. Then the supernatants were centrifuged at 33,000 rpm in a Beckman 70.ITI rotor for $1.5 \mathrm{hr}$ at $4^{\circ} \mathrm{C}$. The final supernatants were concentrated with Centricon-10 Concentrator spin columns (Amicon), aliquotted, and stored at $-70^{\circ} \mathrm{C}$ until use.

Transient transfection of primary retinal cultures. Cultured retinal cells prepared from E8 retina plated on 24-well plates were used for the transient transfection assays. A $2 \mathrm{~kb} E c o \mathrm{RI} / H i n d I I I$ fragment of the $\mathrm{cm} 2$ promoter region that was ligated $5^{\prime}$ of the firefly luciferase reporter gene in the pGL3 expression vector, designated pNMR27 (Rosoff et al., 1996), was used as the $\mathrm{cm} 2$ promoter construct. Cells were transfected by the calcium phosphate precipitation method (Sambrook et al., 1989) with 600 ng/well pNMR27 or pGL3, and $100 \mathrm{ng} /$ well pRSV- $\beta$-galactosidase $(\beta$ gal). The cells were incubated with the DNA/calcium phosphate precipitate for $4 \mathrm{hr}$ and then treated with $10 \%$ glycerol for $3 \mathrm{~min}$. After glycerol shock, retinal cells were treated with control medium, conditioned medium, DEAE flow-through, crude soluble protein extracts, or growth/ neurotrophic factors for $36 \mathrm{hr}$. Cells were lysed and assayed for luciferase and $\beta$-gal activities as described (Johnson and Nathanson, 1994).

Reagents. Actinomycin D was purchased from Sigma. LIF and CNTF were purchased from PeproTech (Rocky Hill, NJ). EGF, NGF (2.5S), and TGF $\beta$ were purchased from Upstate Biotechnology (Lake Placid, NY). BDNF, NT-3, and NT-4 were purchased from Alomone Labs (Jerusalem, Israel). Activin was purchased from Austral Biologicals (San Ramon, CA). Growth-promoting activity (GPA) was a gift from Dr. Rae 
Nishi (Oregon Health Sciences University), GDNF was a gift from Genentech (South San Francisco, CA), and neuregulin (rhGGF2) was a gift from Cambridge Neuroscience (Cambridge, MA). FGF was a gift from Dr. Randall T. Moon (University of Washington), and PDGF was a gift from Dr. Edwin G. Krebs (University of Washington). D-Luciferin was purchased from Analytical Luminescence Laboratories (San Diego, $\mathrm{CA}$ ), and reagents for the chemiluminescent assay for $\beta$-galactosidase activity were purchased from Tropix (Bedford, MA).

\section{RESULTS}

\section{Identification of cell types expressing mAChR in cultured embryonic chick retinal cells}

Antibodies specific for each mAChR subtype (McKinnon and Nathanson, 1995) were used to identify which cell types in cultured embryonic chick retina express $\mathrm{cm} 2, \mathrm{~cm} 3$, and $\mathrm{cm} 4$. Because antibodies that are highly specific on immunoblots and in immunoprecipitation assays can yield nonspecific immunocytochemical staining (S. Hamilton and N. Nathanson, unpublished observations), each antibody was tested for specificity by immunocytochemistry on stably transfected Y1 cells expressing either $\mathrm{cm} 2$ or $\mathrm{cm} 4$, and COS-7 cells transiently expressing $\mathrm{cm} 3$. As shown in Figure 1, each subtype-specific anti-mAChR antibody shows no cross-reactivity for the other subtypes when used for immunocytochemistry.

The marker proteins used for identification of the cell types in the cultured retinal cells are listed in Table 1. As indicated in Figure 2 and Table 1, cm2 is expressed in all ganglion cells and photoreceptors identified by the marker antigens, whereas cm 3 is expressed in some but not all of these cell types. Both $\mathrm{cm} 2$ and $\mathrm{cm} 3$ are expressed in all bipolar cells that are immunoreactive for protein kinase $\mathrm{C} \alpha$ and $\beta$. In contrast, $\mathrm{cm} 4$ is expressed in every neuronal cell type, as well as Müller glia, but does not show $100 \%$ colocalization with any of the marker antigens used. The presence of $\mathrm{mAChR}$ in retinal glia has been demonstrated previously in rabbit retina: glial-enriched retinal cultures showed a mAChRstimulated increase in phosphoinositide turnover (Ghazi and Osborne, 1988). Other pharmacological and electrophysiological studies in rat, salamander, and frog retina have demonstrated the presence of $\mathrm{mAChR}$ in amacrine, bipolar, and ganglion cells (Redburn et al., 1984; Townes-Anderson and Vogt, 1989; Jardon et al., 1992).

To demonstrate that the expression of the three mAChR in cultured embryonic retina is similar to that found in vivo, we immunostained slices of embryonic chick retina with the antimAChR antibodies. We used E14 chick retina, which would be developmentally equivalent to the E9 retina that were cultured for $5 \mathrm{~d}$ for the immunocytochemical experiments described in Figure 2 and Table 1. The $\mathrm{cm} 2$ receptor is expressed in the outer nuclear layer (ONL), including the photoreceptors (PR), the inner nuclear layer (INL), and the inner plexiform layer (IPL), and is expressed in large part in the ganglion cell layer (RGC), in particular, the processes of the ganglion cells (Fig. 3). This pattern of expression agrees well with our results in culture, showing $\mathrm{cm} 2$ expression in the ganglion cells, photoreceptors, and bipolar cells (Fig. 2, Table 1). Figure 3 shows $\mathrm{cm} 3$ expression in the ONL, the outer plexiform layer (OPL), the INL, and a small amount of staining in the IPL. The morphology of the $\mathrm{cm} 3$ positive cells in the INL resembles that of bipolar cells. The pattern of $\mathrm{cm} 3$ staining in vivo is consistent with our findings in culture (Fig. 2, Table 1). Last, $\mathrm{cm} 4$ is widely expressed throughout the chick retina and is present to some degree in all of the cell layers. The prominent staining of two bands in the IPL by the anti-mAChR antibodies is in agreement with the findings of
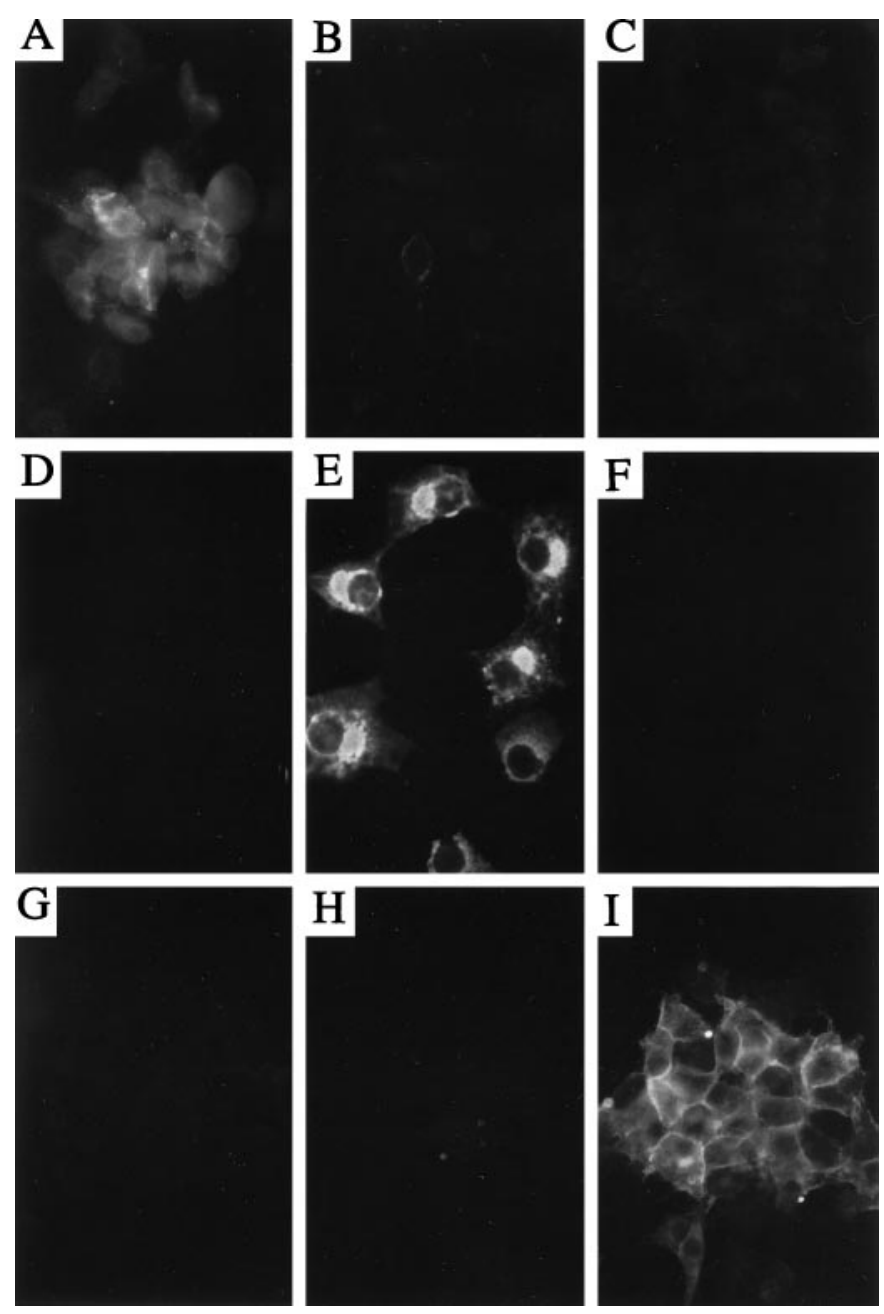

Figure 1. Immunocytochemistry demonstrating specificity of anti$\mathrm{mAChR}$ antibodies. Stably transfected Y1 cells expressing either $\mathrm{cm} 2$ or $\mathrm{cm} 4$ and COS-7 cells transiently expressing $\mathrm{cm} 3$ were grown on poly-Dlysine-coated glass slides and prepared for immunocytochemistry, as described in Materials and Methods. Anti-mAChR antibodies used are as follows: $A-C$, anti-cm2; $D-F$, anti-cm3; $G-I$, anti-cm4. Cells labeled with the anti-mAChR antibodies include the following: $A, D, G, \mathrm{Y} 1 \mathrm{~cm} 2$ cells; $B, E, H$, COS-7 cm 3 cells; $C, F, I, Y 1 \mathrm{~cm} 4$ cells. All photographs were taken at $400 \times$ magnification.

Sugiyama et al. (1977), who showed by radioligand binding the presence of two bands of mAChR binding sites in the IPL of E13 chick retina. Therefore, the expression patterns of $\mathrm{cm} 2, \mathrm{~cm} 3$, and $\mathrm{cm} 4$ in cultured embryonic chick retinal cells closely resemble their respective patterns of expression in vivo.

\section{Conditioned medium selectively increases the expression of $\mathrm{cm} 2$ protein and $\mathrm{mRNA}$}

Previous work with cultured embryonic chick retinal cultures has shown that conditioned medium from mature retinal cultures can increase the expression of the $72 \mathrm{kDa} \mathrm{mAChR}$ species (Skorupa and Klein, 1993). Immunoblot analysis of embryonic chick retina indicates that the $72 \mathrm{kDa}$ species corresponds to the $\mathrm{cm} 2$ receptor (McKinnon and Nathanson, 1995). We cultured retinal cells prepared from E9 retina and measured the expression of $\mathrm{cm} 2$, $\mathrm{cm} 3$, and $\mathrm{cm} 4$ protein, using subtype-specific antibodies by an immunoprecipitation assay. $\mathrm{cm} 2$ protein expression is very low at the beginning of the culture period and increases to $20 \%$ of the total mAChR population by culture day 4 (Fig. $4 A$ ), whereas $\mathrm{cm} 3$ 


\begin{tabular}{|c|c|c|c|c|c|c|}
\hline Marker antigens: & Neurofilament ${ }^{a}$ & $\mathrm{IRBP}^{b}$ & Tenascin $^{c}$ & $\begin{array}{l}\text { Protein kinase } \mathrm{C} \\
\alpha \text { and } \beta^{d}\end{array}$ & Vimentin $^{e}$ & Islet- $1^{f}$ \\
\hline Cell types: & Ganglion & Photoreceptors & Horizontal/Amacrine & Bipolar & Müller glia & Ganglion \\
\hline $\mathrm{cm} 2$ & ++ & ++ & -- & ++ & -- & ++ \\
\hline $\mathrm{cm} 3$ & + & + & -- & ++ & -- & + \\
\hline $\mathrm{cm} 4$ & + & + & + & + & + & + \\
\hline
\end{tabular}

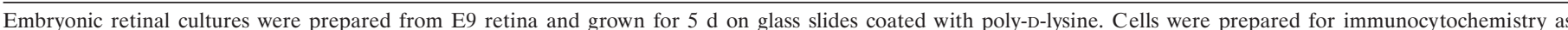

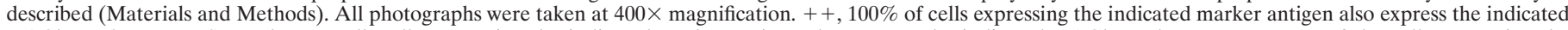

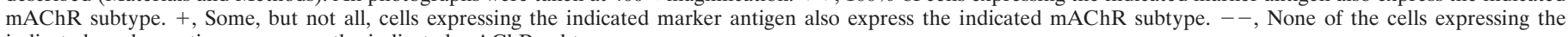
indicated marker antigen expresses the indicated mAChR subtype.

${ }^{a}$ Bradshaw et al., 1995.

${ }^{b}$ Sheedlo and Turner, 1996.

${ }^{c}$ Bartsch et al., 1995.

${ }^{d}$ Hamassaki-Britto et al., 1994. Protein kinase $\mathrm{C} \alpha$ and $\beta$ are expressed only in a subset of bipolar cells in chick retina.

${ }^{e}$ Chabot and Vincent, 1990; Willbold et al., 1995.

${ }^{f}$ Thor et al., 1991.

(Fig. $4 B$ ) and $\mathrm{cm} 4$ (Fig. $4 C$ ) remain relatively constant throughout the culture period at $\sim 12$ and $70 \%$ of the total $\mathrm{mAChR}$ population, respectively. The proportions of $\mathrm{cm} 2, \mathrm{~cm} 3$, and $\mathrm{cm} 4$ protein expression during culture day 5-8 remained essentially unchanged from the values measured at culture day 4 for each receptor (data not shown). These data are in partial agreement with that of Skorupa and Klein (1993), which described the 72 $\mathrm{kDa} \mathrm{mAChR}$ species as increasing in expression and the $86 \mathrm{kDa}$ species as decreasing in expression during the culture period under control conditions. When the retinal cells were cultured in conditioned medium (medium conditioned for $24 \mathrm{hr}$ by retinal cells that had been cultured for 5-8 d), there was a selective increase in $\mathrm{cm} 2$ protein expression (Fig. $4 A$ ), with no significant effect on $\mathrm{cm} 3$ or $\mathrm{cm} 4$ protein levels (Fig. $4 B, C$ ). In the presence of conditioned medium $(\mathrm{CM}), \mathrm{cm} 2$ protein expression achieves maximal control levels by culture day 2.5 and greater than maximal control levels by culture day 4 . These data are consistent with the findings of Skorupa and Klein (1993) describing an increase in expression of the $72 \mathrm{kDa}$ species of $\mathrm{mAChR}$ by culture day 2 in the presence of CM.

The increase in $\mathrm{cm} 2$ protein expression is attributable to an increase in $\mathrm{cm} 2 \mathrm{mRNA}$ levels. Retinal cells were cultured in the presence or absence of CM and RNA isolated on culture days $1-4$, and the amount of mRNA encoding the mAChR was determined by solution hybridization, using subtype-specific riboprobes. As seen with the mAChR proteins, CM selectively increased the level of expression of $\mathrm{cm} 2 \mathrm{mRNA}$, with no significant effect on $\mathrm{cm} 3$ or $\mathrm{cm} 4 \mathrm{mRNA}$ levels (Fig. 5). The time course for the increase in $\mathrm{cm} 2 \mathrm{mRNA}$ levels was similar to that for the increase in $\mathrm{cm} 2$ protein. Most importantly, the increase in $\mathrm{cm} 2$ levels in the presence of CM was attributable to an increase in $\mathrm{cm} 2$ expression rather than to an increase in the number of cells expressing $\mathrm{cm} 2$. Retinal cells were grown on poly-D-lysine-coated glass slides for $2 \mathrm{~d}$ in the presence or absence of $\mathrm{CM}$ and double-labeled with the anti-cm2 antibody and the nuclear stain BO-PRO-3 iodide. In control medium $89 \pm 2 \%$ of the total number of retinal cells was $\mathrm{cm} 2$-positive, whereas in the presence of $90 \% \mathrm{CM}, 86 \pm 3 \%$ of the total number of retinal cells was $\mathrm{cm} 2$-positive $(n=6, \pm \mathrm{SEM})$. In addition, the $\mathrm{cm} 3$ and $\mathrm{cm} 4$ receptor subtypes are expressed in the same cell types as $\mathrm{cm} 2$ (Table 1), but their levels of expression remain unchanged. Therefore, these data indicate that $\mathrm{CM}$ from mature cultured retinal cells contains a secreted factor that selectively increases the expression of $\mathrm{cm} 2 \mathrm{mRNA}$ and protein in cultured retinal cells.

\section{The activity of the cm2-inducing factor is dose and culture age-dependent}

The ability of the $\mathrm{cm} 2$-inducing factor to increase the expression of $\mathrm{cm} 2$ is dose-dependent. Retinal cells were cultured in control medium or the following dilutions of CM: 20,50 , or $90 \%$ (standard dilution of $\mathrm{CM}$ ). On the second day of culture, RNA was isolated from the retinal cells for the solution hybridization assay. The presence of $\mathrm{cm} 2$-inducing activity was directly proportional to the concentration of $\mathrm{CM}$ used to culture the retinal cells, with maximal activity present in the standard 90\% CM (Fig. 6A). In addition, the presence of $\mathrm{cm} 2$-inducing activity in the $\mathrm{CM}$ was dependent on the age of the cultures from which the CM was collected. Retinal cells were cultured for $2 \mathrm{~d}$ in control medium, or $90 \% \mathrm{CM}$ collected from retinal cells on culture days 1,2 , or 3 , or on culture days 5-8 (the standard collection of CM; medium conditioned for a maximum of $24 \mathrm{hr}$ ), and then RNA was isolated for the solution hybridization assay. As clearly shown in Figure $6 B$, secretion of the $\mathrm{cm} 2$-inducing factor into the culture medium did not occur until culture day 3. This time course of secretion of the $\mathrm{cm} 2$-inducing factor coincides with the initiation of the increase in $\mathrm{cm} 2$ protein and mRNA observed under control conditions (Figs. $4 A, 5$ ).

\section{The cm2-inducing factor is a protein}

To begin the biochemical characterization of the $\mathrm{cm} 2$-inducing factor, we used an Amicon Ultrafiltration Cell with a PM10 Diaflo Ultrafilter, which retains molecules that are $>10 \mathrm{kDa}$, to attempt to concentrate the $\mathrm{cm} 2$-inducing factor. Both serum-free (Figs. 7, 9) and serum-containing CM (Fig. 9) were found to contain $\mathrm{cm} 2$-inducing activity after 10 -fold concentration. The $\mathrm{cm} 2$-inducing factor appeared to be positively charged, because the activity from concentrated serum-free conditioned medium (SFCM) was present in the flow-through from a weak anion exchange column of DEAE Sephacel at pH 7.4 (Figs. 7, 9). Preliminary data suggest that the $\mathrm{cm} 2$-inducing factor was retained on a weak cation exchange column of CM Sephadex (C-25), pH 6.5 (data not shown). The $\mathrm{cm} 2$-inducing factor was also sensitive to protease digestion. The flow-through of concentrated SFCM passed over a DEAE Sephacel column was digested 

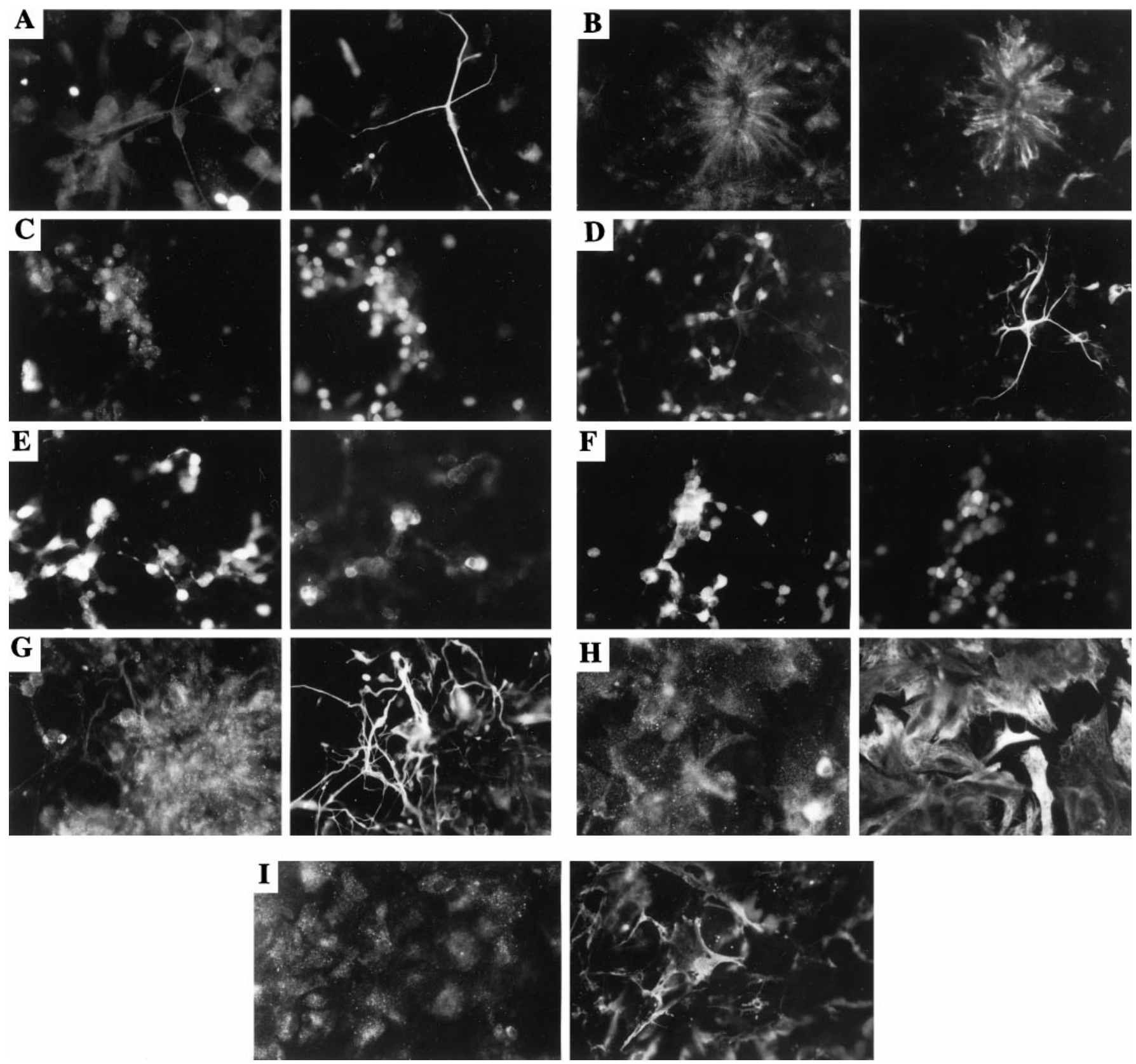

Figure 2. Colocalization of mAChR with markers for retinal neurons and Müller glia. Embryonic retinal cultures were prepared from E9 retina and grown on poly-D-lysine-coated glass slides for $5 \mathrm{~d}$. Cells were prepared for immunocytochemistry, as described in Materials and Methods. mAChR were immunolabeled with FITC-conjugated secondary antibody (shown on the left side of each pair), and retinal cell markers were immunolabeled with rhodamine-conjugated secondary antibody (shown on the right side of each pair). See Materials and Methods and Table 1 for specificity of marker antigens. All photographs were taken at $400 \times$ magnification. Colocalizations shown include the following: $A$, $\mathrm{cm} 2$ and neurofilament colocalizing in ganglion cells; $B, \mathrm{~cm} 2$ and IRBP colocalizing in photoreceptors; $C, \mathrm{~cm} 2$ and Islet-1 colocalizing in ganglion cells; $D$, cm 3 and neurofilament colocalizing in ganglion cells; $E, \mathrm{~cm} 3$ and protein kinase $\mathrm{C}(\alpha$ and $\beta)$ colocalizing in bipolar cells; $F, \mathrm{~cm} 3$ and Islet-1 colocalizing in ganglion cells; $G$, cm 4 and neurofilament colocalizing in ganglion cells; $H, \mathrm{~cm} 4$ and vimentin colocalizing in Müller glia; $I, \mathrm{~cm} 4$ and tenascin colocalizing in amacrine and horizontal cells.

with either Pronase or proteinase $\mathrm{K}$ and used to treat retinal cultures that were harvested on culture day 2, and RNA was isolated for the solution hybridization assay. Protease digestion of the DEAE column flow-through greatly reduced or eliminated the $\mathrm{cm}$ 2-inducing activity (Fig. 7). The $\mathrm{cm} 2$-inducing factor also was inactivated by boiling for $5 \mathrm{~min}$ (data not shown). Together, these data indicate that the $\mathrm{cm} 2$-inducing factor is a protein that is $>10 \mathrm{kDa}$ and cationic at neutral $\mathrm{pH}$.

\section{The cm2-inducing factor stimulates $\mathrm{cm} 2$ gene transcription}

The increase in $\mathrm{cm} 2$ mRNA stimulated by the $\mathrm{cm} 2$-inducing factor could be caused by an increase in $\mathrm{cm} 2$ gene transcription or an increase in cm 2 mRNA stability. To test the latter hypothesis, we cultured retinal cells in the presence or absence of standard $\mathrm{CM}$ for $2 \mathrm{~d}$. Before RNA isolation, the cells were treated with 


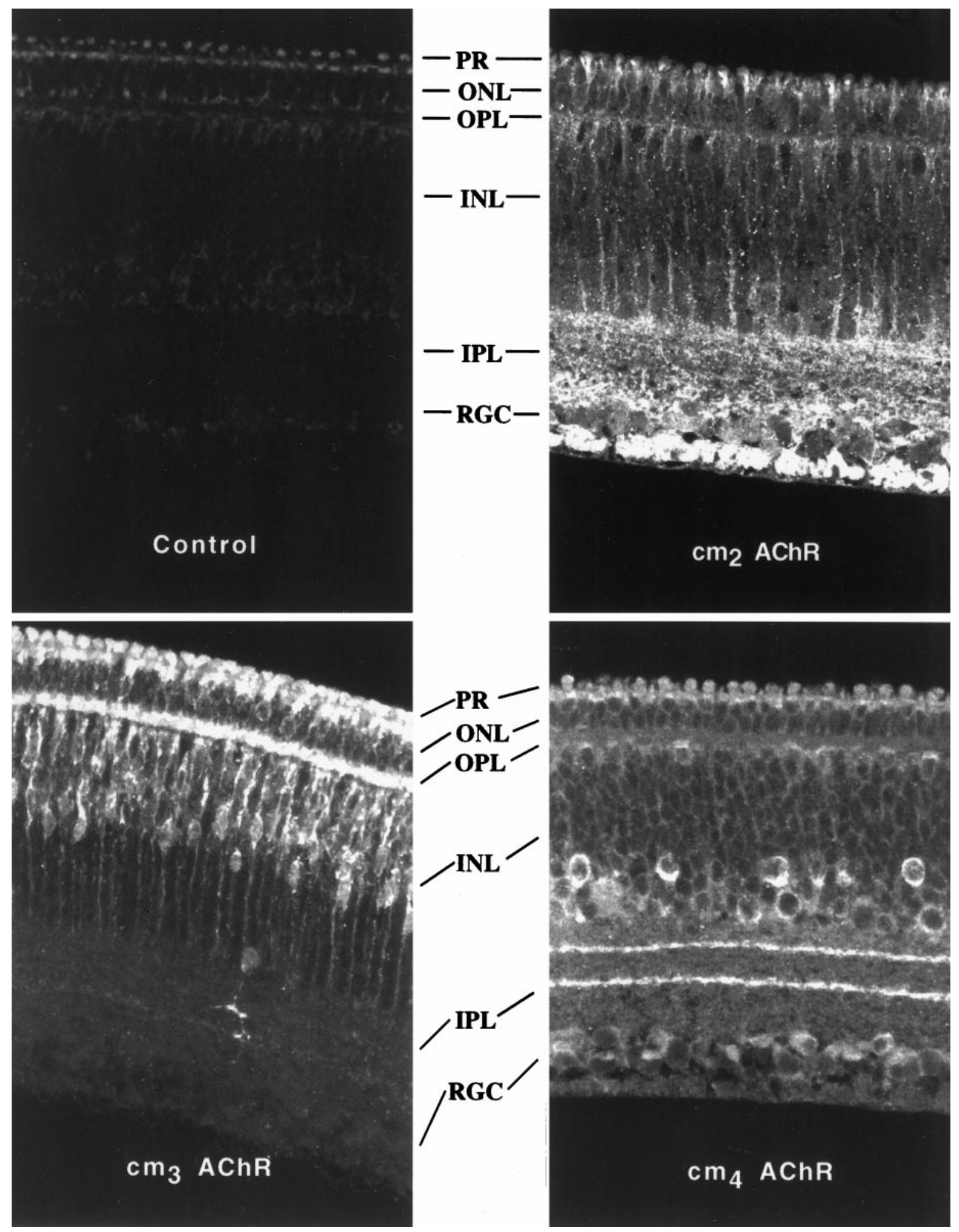

Figure 3. Immunolocalization of $\mathrm{mAChR}$ in embryonic retinal slices. E14 chick retinal slices were prepared for immunocytochemistry, as described in Materials and Methods, and labeled with no primary antibody (control panel), anti-cm2 ( $\mathrm{cm} 2$ panel), anti- $\mathrm{cm} 3(\mathrm{~cm} 3 \mathrm{panel})$, or anti-cm4 ( $\mathrm{cm} 4$ panel). Photographs were taken with confocal microscopy. Retinal cells layers are labeled as follows: $R G C$, retinal ganglion cells; $I P L$, inner plexiform layer; $I N L$, inner nuclear layer; $O P L$, outer plexiform layer; $O N L$, outer nuclear layer; $P R$, photoreceptors.

PBS or $10 \mu \mathrm{M}$ actinomycin D for $0,2,4$, or $6 \mathrm{hr}$. The $\mathrm{cm} 2$-inducing factor did not decrease the apparent degradation rate of the $\mathrm{cm} 2$ mRNA (Fig. 8), suggesting that the $\mathrm{cm} 2$-inducing factor stimulates an increase in $\mathrm{cm} 2$ mRNA by increasing the rate of tran- scription of the $\mathrm{cm} 2$ gene. The $\mathrm{cm} 2$ promoter has been cloned and characterized by our laboratory (Rosoff et al., 1996). We used a $\mathrm{cm} 2$ promoter/luciferase reporter gene construct containing $2 \mathrm{~kb}$ of the $\mathrm{cm} 2$ promoter (Rosoff et al., 1996) to analyze the effects of 

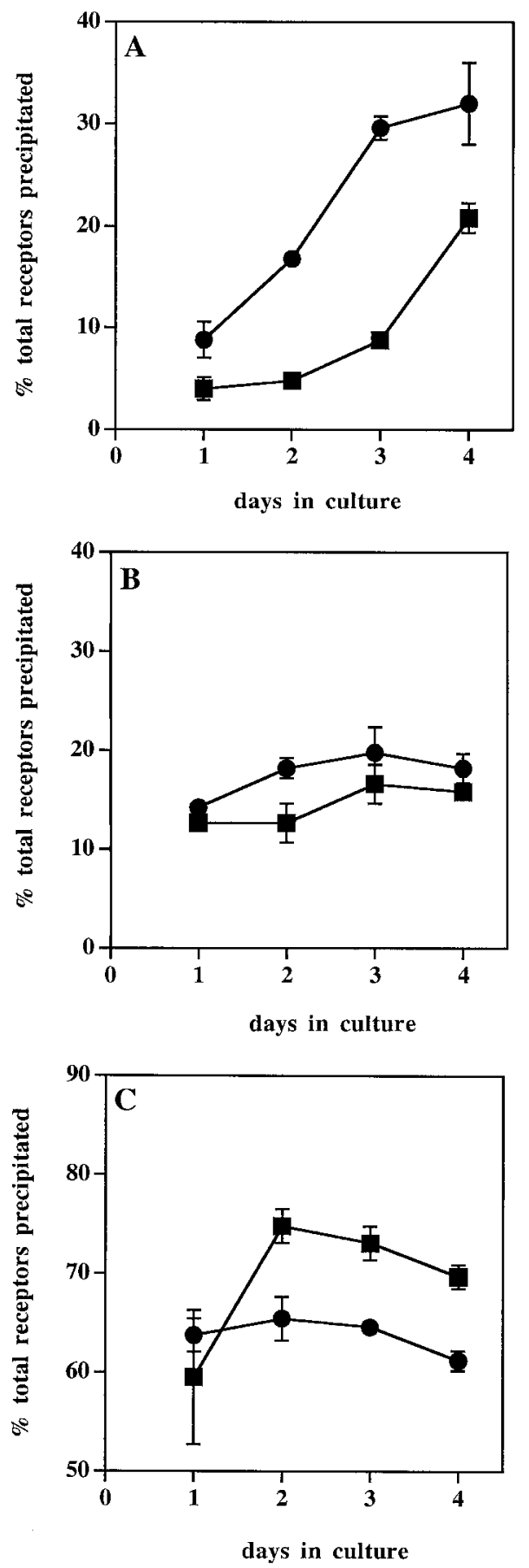

Figure 4. Effect of conditioned medium on mAChR protein expression in cultured embryonic chick retinal cells. Embryonic chick retinal cultures prepared from E9 retina were grown in the presence (filled circles) or absence ( filled squares) of $90 \%$ conditioned medium and harvested for the immunoprecipitation assay (Materials and Methods) on the culture day indicated. Conditioned medium consisted of medium conditioned by retinal cultures for a maximum of $24 \mathrm{hr}$. The conditioned medium was collected from retinal cells grown in culture for 5-8 d. Data represent the percentage of $\mathrm{cm} 2(A), \mathrm{cm} 3(B)$, or $\mathrm{cm} 4(C)$ immunoprecipitated from the total mAChR population. Values are the mean \pm SEM; $n=3-9$.

$\mathrm{cm} 2$-inducing factor on $\mathrm{cm} 2$ transcription. To lessen the probability of the cultures producing their own $\mathrm{cm} 2$-inducing factor, which begins to occur at culture day 3 in retinal cells cultured from E9 retina (see Fig. 5B), we prepared retinal cultures from E8

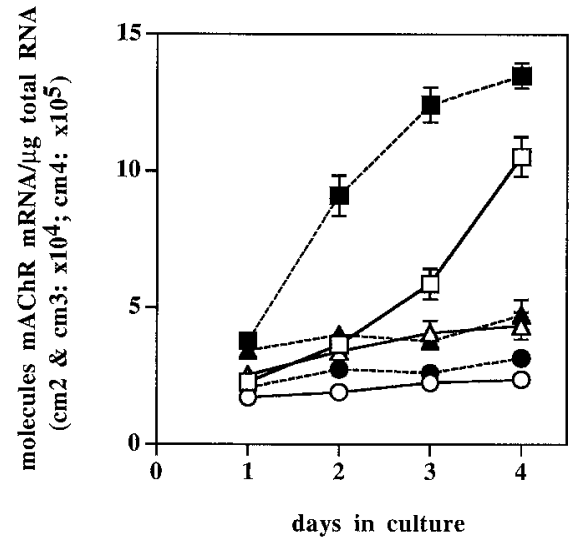

Figure 5. Effect of conditioned medium on mAChR mRNA expression in cultured embryonic chick retinal cells. Embryonic chick retinal cultures prepared from E9 retina were grown in the presence (filled symbols) or absence (open symbols) of $90 \%$ conditioned medium and harvested to isolate RNA for the solution hybridization assay (Materials and Methods) on the culture day indicated. Conditioned medium consisted of medium conditioned by retinal cultures for a maximum of $24 \mathrm{hr}$. The conditioned medium was collected from retinal cells grown in culture for 5-8 d. Data represent the number of molecules of $\mathrm{cm} 2$ (squares), $\mathrm{cm} 3$ (circles), or $\mathrm{cm} 4$ (triangles) mRNA per microgram of total RNA. Values are the mean \pm SEM; $n=4-10$.

retina for the transfection experiments; the cultures were transfected on culture day 1, treated for $36 \mathrm{hr}$, and lysed for the luciferase and $\beta$-galactosidase assays on culture day 3 . Retinal cells transfected with the $\mathrm{cm} 2$ promoter/luciferase reporter gene construct were treated with control medium, standard CM, concentrated CM, concentrated SFCM, or DEAE flow-through (concentrated SFCM used as start material). DEAE Sephacel retains transferrin, the sole protein component added to the serum-free medium, as determined by SDS polyacrylamide gel electrophoresis (data not shown), but not the $\mathrm{cm} 2$-inducing activity, making the DEAE column chromatography a useful purification step. The $\mathrm{cm} 2$-inducing factor stimulates the transcription of the $\mathrm{cm} 2$ promoter in a dose-dependent manner from all preparations of $\mathrm{CM}$ tested, indicating that the $\mathrm{cm} 2$-inducing factor increases the levels of $\mathrm{cm} 2 \mathrm{mRNA}$ by increasing the rate of transcription of the $\mathrm{cm} 2$ gene (Fig. 9). Based on the protein concentrations of the concentrated CM $(30 \mu \mathrm{g} / \mu \mathrm{l})$, the concentrated SFCM $(1 \mu \mathrm{g} / \mu \mathrm{l})$, the DEAE flow-through $(\sim 10 \mathrm{ng} / \mu \mathrm{l})$ determined in one experiment, and the amount of media/flowthrough, which gives a twofold induction of the $\mathrm{cm} 2$ promoter, there is at least a 600 -fold and a 40 -fold increase in specific activity of the $\mathrm{cm} 2$-inducing factor after DEAE column chromatography of concentrated SFCM, as compared with unfractionated concentrated CM and unfractionated concentrated SFCM, respectively.

Hofmann (1988) found that conditioned medium from cultured embryonic chick retinal cells contained a secreted factor that caused an increase in choline acetyltransferase (ChAT) activity in these cells. Extracts prepared from embryonic chick retina and from ciliary body, iris, and pigment epithelium (CIPE) had the same effect as conditioned medium on ChAT activity in the retinal cultures, whereas brain extract was found to be ineffective. It was suggested that the ChAT-inducing factor present in CIPE extract was ciliary neurotrophic factor (CNTF) or a related protein, because CIPE is a known source of CNTF (Hofmann, 1988). We prepared soluble protein extracts from E12 retina, 

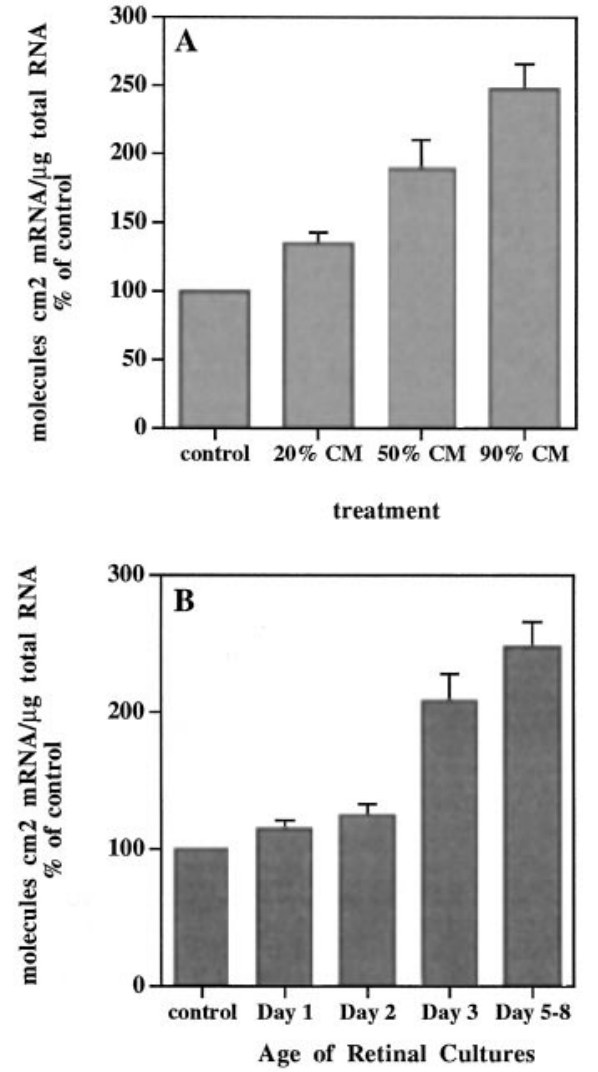

Figure 6. The $\mathrm{cm} 2$-inducing activity is dose and culture age-dependent. $A$, Embryonic chick retinal cultures prepared from $\mathrm{E} 9$ retina were grown in the presence of control medium or three dilutions of conditioned medium and harvested on culture day 2 to isolate RNA for the solution hybridization assay. Conditioned medium consisted of medium conditioned by retinal cultures for a maximum of $24 \mathrm{hr}$. The conditioned medium was collected from retinal cells grown in culture for 5-8 d. Molecules of $\mathrm{cm} 2 \mathrm{mRNA}$ per microgram of total RNA were measured, and data are presented as a percentage of control values. Data shown are the mean $\pm \mathrm{SEM} ; n=3-11$. $B$, Embryonic chick retinal cultures prepared from E9 retina were grown in the presence of control medium or $90 \%$ conditioned medium recovered from retinal cells grown for $1,2,3$, or $5-8$ $\mathrm{d}$ (standard conditioned medium; conditioned medium was conditioned by retinal cultures for a maximum of $24 \mathrm{hr}$ ). Retinal cells were harvested on culture day 2 to isolate RNA for the solution hybridization assay. Molecules of $\mathrm{cm} 2$ mRNA per microgram of total RNA were quantitated, and data are expressed as a percentage of control values. Data shown are the mean $\pm \mathrm{SEM} ; n=3-11$.

E12-E15 ventricle, and E15 brain of embryonic chicks to determine whether any of these tissues might be a source of the $\mathrm{cm} 2$-inducing factor. However, treatment of retinal cultures with each of these soluble protein extracts did not show induction of the $\mathrm{cm} 2$ promoter construct (Table 2). To address whether the $\mathrm{cm} 2$-inducing factor is an identified neurotrophic factor or cytokine, we tested 14 proteins for cm2-inducing activity by either solution hybridization or the luciferase assay. As shown in Table 2, CNTF, LIF, GDNF, NGF, GPA, neuregulin, EGF, bFGF, PDGF, activin, BDNF, NT-3, NT-4, and TGF $\beta$ did not exhibit $\mathrm{cm} 2$-inducing activity, indicating that the $\mathrm{cm} 2$-inducing factor may represent a previously unidentified neuronal regulatory factor.

\section{DISCUSSION}

We show here that the ontogenesis of $\mathrm{cm} 2 \mathrm{mAChR}$ expression in the chick retina in vivo is recapitulated during development in

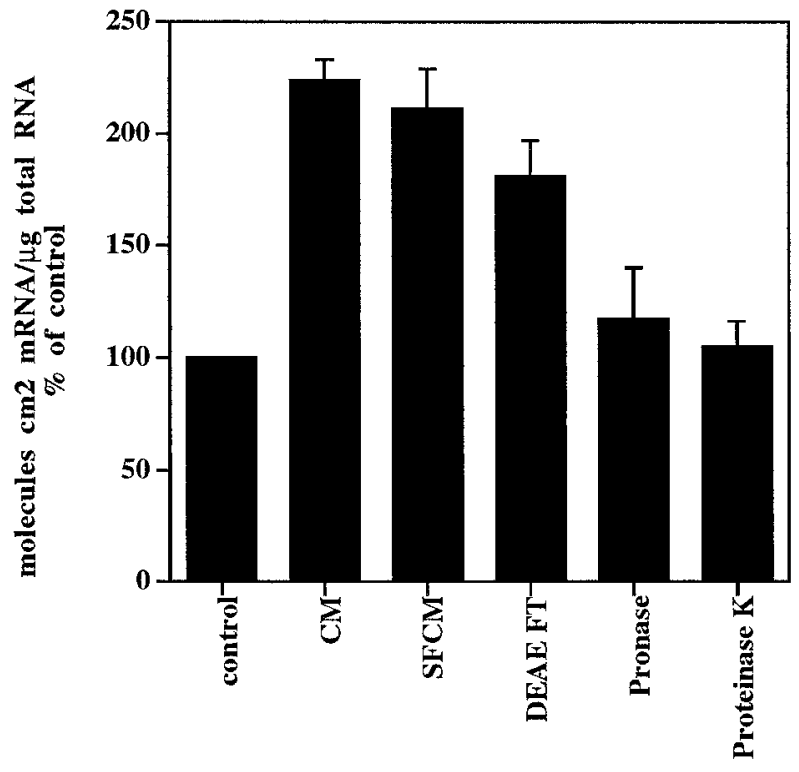

treatment

Figure 7. The $\mathrm{cm} 2$-inducing factor is a protein: it can be concentrated and is sensitive to proteases. Embryonic chick retinal cultures prepared from E9 retina were grown in the presence of control medium or one of the following: $C M, 90 \%$ conditioned medium; SFCM, $10 \%$ serum-free conditioned medium concentrated 10-fold; DEAE FT, $10 \%$ flow-through from a DEAE Sephacel column over which concentrated SFCM was passed; Pronase, 10\% DEAE FT that has been digested with $2 \mathrm{mg} / \mathrm{ml}$ Pronase; Proteinase K, $10 \%$ DEAE FT that has been digested with 40 $\mathrm{mg} / \mathrm{ml}$ proteinase $\mathrm{K}$. See Materials and Methods for details regarding the procedure for concentrating conditioned medium, DEAE column chromatography, and protease treatments. Retinal cells were harvested on culture day 2 to isolate RNA for the solution hybridization assay. Molecules of $\mathrm{cm} 2$ mRNA per microgram of total RNA were quantitated, and data are expressed as a percentage of control values. Data shown are the mean $\pm \mathrm{SEM} ; n=3-9$.

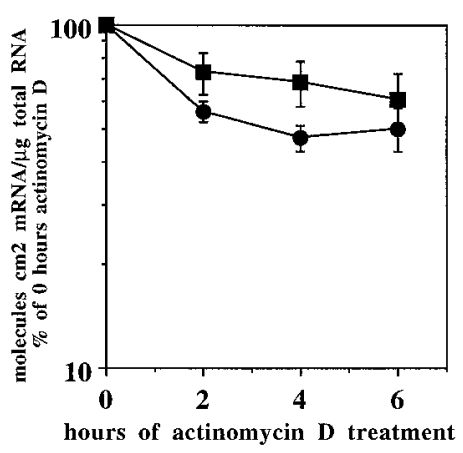

Figure 8. The $\mathrm{cm} 2$-inducing factor does not decrease the rate of $\mathrm{cm} 2$ mRNA degradation. Embryonic chick retinal cultures were prepared from E9 retina and grown in the presence (filled circles) or absence (filled squares) of $90 \%$ conditioned medium for $2 \mathrm{~d}$. On culture day 2, retinal cells were treated with PBS or $10 \mu \mathrm{M}$ actinomycin D for $0,2,4$, or $6 \mathrm{hr}$ and then harvested to isolate RNA for the solution hybridization assay. Data represent the number of molecules of $\mathrm{cm} 2 \mathrm{mRNA}$ per microgram of total RNA, expressed as a percentage of $0 \mathrm{hr}$ PBS treatment for the PBStreated cells or $0 \mathrm{hr}$ actinomycin $\mathrm{D}$ treatment for the actinomycin D-treated cells. Values are the mean \pm SEM; $n=3-4$.

vitro and demonstrate that cultured embryonic chick retinal cells secrete a protein that transcriptionally regulates the expression of the $\mathrm{cm} 2$ gene.

By immunolocalization, $\mathrm{cm} 4$ was found to be the most widely 


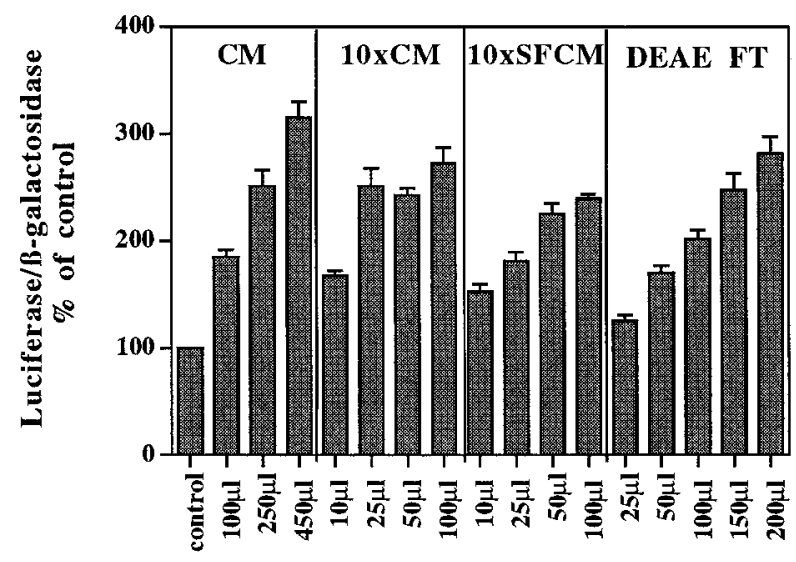

volume added/well

Figure 9. The $\mathrm{cm} 2$-inducing factor stimulates transcription of the $\mathrm{cm} 2$ gene in a dose-dependent manner. Embryonic chick retinal cultures prepared from E8 retina were plated in 24-well plates and transfected on culture day 1 with the $\mathrm{cm} 2$ promoter/luciferase reporter gene construct, as described in Materials and Methods. After transfection, retinal cells were treated for $36 \mathrm{hr}$ with the following: $C M$, conditioned medium; $10 \times C M$, CM concentrated 10-fold; $10 \times$ SFCM, serum-free CM concentrated 10fold; $10 \times D E A E F T$, flow-through from a DEAE Sephacel column over which $10 \times$ SFCM was passed twice (Materials and Methods). Volumes indicate the amount of conditioned medium/flow-through added per well in a total volume of $500 \mu \mathrm{l}$. After the $36 \mathrm{hr}$ treatment, retinal cells were lysed for the luciferase and $\beta$-galactosidase assays (Materials and Methods). The data represent luciferase activity/ $\beta$-galactosidase activity, expressed as a percentage of control. Values are the mean \pm SEM; $n=3$.

expressed receptor in cultured embryonic chick retina, present in all neuronal cells types as well as the Müller glia. In contrast, $\mathrm{cm} 2$ and $\mathrm{cm} 3$ receptors were present only in the ganglion cells, photoreceptors, and a subset of bipolar cells that are immunoreactive for protein kinase $\mathrm{C} \alpha$ and $\beta$ (Fig. 2, Table 1). However, the localization of $\mathrm{cm} 2$ to the ganglion cells and photoreceptors and the localization of $\mathrm{cm} 2$ and $\mathrm{cm} 3$ to the bipolar cells were much more prominent than the presence of $\mathrm{cm} 4$ in these cell types. Importantly, we have shown that the expression of the three receptor subtypes in embryonic chick retina in vivo (see Fig. 3) is consistent with our results in culture. In addition, our results are consistent with those of Sugiyama et al. (1977), who found that radiolabeled $\mathrm{mAChR}$ were present in two bands in the IPL of E13 chick retina. Interestingly, Sugiyama et al. (1977) also reported that there were three bands of $\mathrm{mAChR}$ in the IPL of adult chickens. The levels of $\mathrm{cm} 2, \mathrm{~cm} 3$, and $\mathrm{cm} 4$ receptors change dramatically during development (McKinnon and Nathanson, 1995). Immunostaining of posthatched chick retinal slices showed expression of $\mathrm{cm} 2$ and $\mathrm{cm} 4$ mainly in amacrine and ganglion cells and showed expression of $\mathrm{cm} 3$ mainly in bipolar and amacrine cells. Consistent with the results of Sugiyama et al. (1977), there were three bands of immunostained mAChR in the IPL of the post-hatched chick retina (A. Fischer, L. McKinnon, N. Nathanson, and W. Stell, unpublished observations).

Retinal cells cultured in the presence of conditioned medium collected from mature cultured retinal cells show a selective increase in $\mathrm{cm} 2$ protein and mRNA expression. Interestingly, the expression of $\mathrm{cm} 3$ and $\mathrm{cm} 4$ is unaffected by the conditioned medium (see Figs. 4, 5), although these receptors are coexpressed in the retinal cells that contain $\mathrm{cm} 2$. By culture day 2 conditioned medium stimulate an increase in $\mathrm{cm} 2$ protein and mRNA expression equivalent to levels of expression observed on culture day 4
Table 2. Soluble protein extracts, neurotrophic factors, and growth factors that do not exhibit $\mathrm{cm} 2$-inducing activity

A. Tested by solution hybridization assay for $\mathrm{cm} 2$-inducing activity

Treatment

GDNF, $50 \mathrm{ng} / \mathrm{ml}$

GPA, $10 \mathrm{ng} / \mathrm{ml}$

LIF, $50 \mathrm{ng} / \mathrm{ml}$

Neuregulin, $100 \mathrm{ng} / \mathrm{ml}$

NGF, $100 \mathrm{ng} / \mathrm{ml}$

$\frac{\% \text { Control }}{102 \pm 11}$
$118 \pm 7$
$114 \pm 9$
$134 \pm 11$
$104 \pm 9$

B. Tested by luciferase assay for $\mathrm{cm} 2$-inducing activity

Treatment

E15 chick brain extract, $200 \mu \mathrm{g} / \mathrm{ml}$

E12-E15 chick ventricle extract, $200 \mu \mathrm{g} / \mathrm{ml}$

E12 chick retina extract, $200 \mu \mathrm{g} / \mathrm{ml}$

Activin, $100 \mathrm{ng} / \mathrm{ml}$

BDNF, $50 \mathrm{ng} / \mathrm{ml}$

CNTF, $50 \mathrm{ng} / \mathrm{ml}$

EGF, $100 \mathrm{ng} / \mathrm{ml}$

bFGF, $50 \mathrm{ng} / \mathrm{ml}$

NT-3, $50 \mathrm{ng} / \mathrm{ml}$

NT-4, $50 \mathrm{ng} / \mathrm{ml}$

PDGF, $30 \mathrm{ng} / \mathrm{ml}$

$\mathrm{TGF} \beta, 10 \mathrm{ng} / \mathrm{ml}$

A, Embryonic chick retinal cultures prepared from E9 retina were grown in the presence of the following growth or neurotrophic factors: glial cell line-derived neurotrophic factor (GDNF), growth-promoting activity (GPA), leukemia inhibitory factor (LIF), neuregulin (rhGGF2), and nerve growth factor (NGF). The cells were harvested on day 2 of culture to isolate RNA for the solution hybridization assay. The data are presented as a percentage of control; values are the mean \pm SEM; $n=3-6$.

B, Embryonic chick retinal cultures prepared from E8 retina were plated in 24-well plates and transfected on culture day 1 with the $\mathrm{cm} 2$ promoter-luciferase reporter gene construct, as described in Materials and Methods. After transfection, the cells were treated for $36 \mathrm{hr}$ with soluble protein extracts from embryonic chick brain, ventricle, or retina (see Materials and Methods for the preparation of soluble protein extracts) or the following growth or neurotrophic factors: activin, brain-derived neurotrophic factor (BDNF), ciliary neurotrophic factor (CNTF), epidermal growth factor (EGF), basic fibroblast growth factor (bFGF), neurotrophin-3 (NT-3), neurotrophin-4 (NT-4), platelet-derived growth factor (PDGF), and transforming growth factor- $\beta$ (TGF $\beta)$. After the $36 \mathrm{hr}$ treatment, retinal cells were lysed for the luciferase and $\beta$-galactosidase assays. The data represent luciferase activity $/ \beta$ galactosidase activity, expressed as a percentage of control. Values are the mean \pm $\mathrm{SD} ; n=2-3$.

under control culture conditions. In addition, $\mathrm{cm} 2$ protein and mRNA levels seen on culture day 4 in the presence of conditioned medium exceed the control levels of $\mathrm{cm} 2$ protein and mRNA expression at culture day 4 (see Figs. $4 A, 5$ ). This increase in $\mathrm{cm} 2$ levels is attributable to an increase in the extent of $\mathrm{cm} 2$ expression rather than to an increase in the number of cells expressing $\mathrm{cm} 2$.

The production of the $\mathrm{cm} 2$-inducing factor appears to be developmentally regulated: its production does not occur until the third day of culture (Fig. 6B). This onset of $\mathrm{cm} 2$-inducing factor production is in agreement not only with the observed initial increase in $\mathrm{cm} 2$ protein and mRNA at culture day 3 (Figs. $4 A, 5$ ) but also with the expression of $\mathrm{cm} 2$ in vivo. $\mathrm{cm} 2$ protein is undetectable in the chick retina at E9 and begins to increase in expression at E12. A similar expression pattern is found for $\mathrm{cm} 2$ mRNA at E9 and E12 in vivo (McKinnon and Nathanson, 1995). If we consider that culture day 3 of $\mathrm{E} 9$ dissociated retinal cells is developmentally equivalent to E12, the onset of production and/or secretion of the $\mathrm{cm} 2$-inducing factor at culture day 3 correlates well with the in vivo developmental regulation of $\mathrm{cm} 2$ gene induction. 
The $\mathrm{cm} 2$-inducing factor secreted by cultured retinal cells is a protein. The factor is retained when serum-free or serumcontaining conditioned medium is concentrated to remove all molecules with a molecular weight smaller than $10 \mathrm{kDa}$. The cm2-inducing activity present in concentrated SFCM can be separated from the transferrin, the only protein component present in the serum-free medium, by using DEAE Sephacel chromatography. Transferrin is retained by the DEAE column (data not shown), but the $\mathrm{cm} 2$-inducing activity appears in the flow-through of the column when applied at neutral pH (Fig. 7). Treatment of the DEAE column flow-through with the proteases Pronase and proteinase K effectively destroyed the $\mathrm{cm} 2$-inducing activity (Fig. 7). Preliminary results indicate that the activity is retained by a weak cation exchange column at $\mathrm{pH} 6.5$ (data not shown), which would indicate that the $\mathrm{cm} 2$-inducing factor has the properties of a cationic protein. Crude soluble protein extracts from the retina, brain, and ventricle of embryonic chicks were not effective in inducing $\mathrm{cm} 2$ expression in cultured retinal cells (Table 2). The $\mathrm{cm} 2$-inducing factor may be produced only in culture, or the concentration of the $\mathrm{cm} 2$-inducing factor is much lower in the retina in vivo than it is in dissociated retinal cultures so that its activity would not be detected in our crude soluble protein extract preparations.

There are two potential pathways by which the $\mathrm{cm} 2$-inducing factor could stimulate an increase in $\mathrm{cm} 2 \mathrm{mRNA}$ expression in cultured retinal cells: an increase in mRNA stability or an increase in gene transcription. We tested the effect of the $\mathrm{cm} 2$ inducing factor on $\mathrm{cm} 2 \mathrm{mRNA}$ stability by treating retinal cells with actinomycin D in the presence or absence of conditioned medium, as shown in Figure 8. The apparent rate of $\mathrm{cm} 2 \mathrm{mRNA}$ degradation was relatively unchanged, if not slightly increased, by the $\mathrm{cm} 2$-inducing factor when compared with retinal cells cultured in control medium. Moreover, Figure 9 clearly demonstrates that the $\mathrm{cm} 2$-inducing factor activates transcription of the $\mathrm{cm} 2$ promoter in a dose-dependent manner. DEAE chromatography of concentrated SFCM provided a 600-fold increase in specific activity when the flow-through is compared with concentrated CM and a 40-fold increase in specific activity when the flow-through is compared with the concentrated SFCM.

Recently, our laboratory cloned and characterized the $\mathrm{cm} 2$ promoter region of the $\mathrm{cm} 2$ gene (Rosoff et al., 1996). When the $\mathrm{cm} 2$ promoter is expressed in SN56 cells, a mouse septal/neuroblastoma cell line, the cytokines CNTF and LIF cause a significant induction of $\mathrm{cm} 2$ promoter transcription, the first demonstration of cytokine regulation of $\mathrm{mAChR}$ expression. The general regions of the $\mathrm{cm} 2$ promoter required for the induction by cytokines have been determined (Rosoff et al., 1996). Interestingly, CNTF and LIF, as well as several other trophic factors, had no effect on the expression of $\mathrm{cm} 2$ in cultured retinal cells (Table 2 ). The regulation of expression of mAChR by homologous (Habecker and Nathanson, 1992) or heterologous (Jackson and Nathanson, 1995) receptor activation or by cytokines or neurotrophic factors can have important physiological consequences in the tissue in which $\mathrm{mAChR}$ are expressed. In the retina the $\mathrm{mAChR}$ has an important role in the processing of visual information in addition to a potential role in the development of the neural retina, such as the formation of the optic cup (Yamashita and Fukuda, 1993). mAChR may regulate the function of the ON/OFF pathway bipolar cells (Bonaventure et al., 1989; Jardon et al., 1992); regulate the input and output of amacrine, bipolar, ganglion, and horizontal cells (Townes-Anderson and Vogt, 1989); regulate the activity of brisk ganglion cells (Schmidt et al.,
1987); and mediate the excitation of directionally selective ganglion cells (Kittila and Massey, 1997). $\mathrm{cm} 2$ and $\mathrm{cm} 3$ were shown to be expressed in the ganglion, bipolar, and photoreceptor cells, whereas $\mathrm{cm} 4$ was found in all cell types of the neural retina (see Figs. 2, 3, Table 1). It is likely that each of these receptors has a unique role not only in the functions of the adult retina but perhaps in the embryonic development of the retina, and the levels of expression of each of these receptors may be critical to those functions. The $\mathrm{cm} 2$-inducing factor may represent a novel neuronal regulatory factor involved in developmental regulation of the expression of the $\mathrm{cm} 2 \mathrm{mAChR}$ in embryonic chick retina.

\section{REFERENCES}

Bartsch S, Husmann K, Schachner M, Bartsch U (1995) The extracellular matrix molecule tenascin: expression in the developing chick retinotectal system and substrate properties for retinal ganglion cell neurites in vitro. Eur J Neurosci 7:907-916.

Bonaventure N, Jardon B, Sahel J, Wioland N (1989) Neurotransmission in the frog retina: possible physiological and histological correlations. Doc Ophthalmol 72:71-82.

Bradshaw AD, McNagny KM, Gervin DB, Cann GM, Graf T, Clegg DO (1995) Integrin $\alpha 2 \beta 1$ mediates interactions between developing embryonic retinal cells and collagen. Development 121:3593-3602.

Chabot P, Vincent M (1990) Transient expression of an intermediate filament-associated protein (IFAPa-400) during in vivo and in vitro differentiation of chick embryonic cells derived from neuroectoderm. Dev Brain Res 54:195-204.

de la Rosa EJ, Bondy CA, Hernández-Sánchez C, Wu X, Zhon J, López-Carranza A, Scavo LM, de Pablo F (1994) Insulin and insulinlike growth factor system components gene expression in the chicken retina from early neurogenesis until late development and their effect on neuroepithelial cells. Eur J Neurosci 6:1801-1810.

Ghazi H, Osborne NN (1988) Agonist-induced stimulation of inositol phosphates in primary rabbit retinal cultures. J Neurochem 50:1851-1858.

Habecker BA, Nathanson NM (1992) Regulation of muscarinic acetylcholine receptor mRNA expression by activation of homologous and heterologous receptors. Proc Natl Acad Sci USA 89:5035-5038.

Hamassaki-Britto DE, Brzozowska-Prechtl A, Karten HJ, Lindstrom JM (1994) Bipolar cells of the chick retina containing $\alpha$-bungarotoxinsensitive nicotinic acetylcholine receptors. Vis Neurosci 11:63-70.

Hofmann H-D (1988) Development of cholinergic retinal neurons from embryonic chicken in monolayer cultures: stimulation by glial cellderived factors. J Neurosci 8:1361-1369.

Jackson DA, Nathanson NM (1995) Subtype-specific regulation of muscarinic receptor expression and function by heterologous receptor activation. J Biol Chem 270:22374-22377.

Jardon B, Bonaventure N, Scherrer E (1992) Possible involvement of cholinergic and glycinergic amacrine cells in the inhibition exerted by the ON retinal channel on the OFF retinal channel. Eur J Pharmacol 210:201-207.

Johnson JA, Nathanson NM (1994) Differential requirements for p $21^{\text {ras }}$ and protein kinase $\mathrm{C}$ in the regulation of neuronal gene expression by nerve growth factor and neurokines. J Biol Chem 269:18856-18863.

Kittila CA, Massey SC (1997) Pharmacology of directionally selective ganglion cells in the rabbit retina. J Neurophysiol 77:675-689.

Large TH, Rauh JJ, DeMello FG, Klein WL (1985) Two molecular weight forms of muscarinic acetylcholine receptors in the avian central nervous system: switch in predominant form during differentiation of synapses. Proc Natl Acad Sci USA 82:8785-8789.

McKinnon LA, Nathanson NM (1995) Tissue-specific regulation of muscarinic acetylcholine receptor expression during embryonic development. J Biol Chem 270:20636-20642.

Nathanson NM (1987) Molecular properties of the muscarinic acetylcholine receptor. Annu Rev Neurosci 10:195-236.

Peppel K, Baglioni C (1990) A simple and fast method to extract RNA from tissue culture cells. Biotechnology 9:711-713.

Redburn DA, Donoso JA, Mitchell CK, Gomez-Ramos P, Samson FE (1984) Kainic acid-induced denervation supersensitivity of the nicotinic, cholinergic receptors in ganglion cells of the rat retina. Exp Eye Res 38:449-461. 
Reh TA (1992) Cellular interactions determine neuronal phenotypes in rodent retinal cultures. J Neurobiol 23:1067-1083.

Rosoff ML, Wei J, Nathanson NM (1996) Isolation and characterization of the chicken $\mathrm{m} 2$ acetylcholine receptor promoter region: induction of gene transcription by leukemia inhibitory factor and ciliary neurotrophic factor. Proc Natl Acad Sci USA 93:14889-14894.

Sambrook J, Fritsch EF, Maniatis T (1989) Standard protocol for calcium phosphate-mediated transfection of adherent cells. In: Molecular cloning: a laboratory manual (Ford N, Ferguson M, eds), pp 16.3316.36. Cold Spring Harbor, NY: Cold Spring Harbor Laboratory.

Schmidt M, Humphrey MF, Wässle H (1987) Action and localization of acetylcholine in the cat retina. J Neurophysiol 58:997-1015.

Sheedlo HJ, Turner JE (1996) Effects of retinal pigment epithelial cell secreted factors on neonatal rat retinal explant progenitor cells. J Neurosci Res 44:519-531.

Skorupa AF, Klein WL (1993) Developmentally regulated secreted factors control expression of muscarinic receptor subtypes in embryonic chick retina. J Neurochem 60:2087-2097.

Sugiyama H, Daniels MP, Nirenberg M (1977) Muscarinic acetylcholine receptors of the developing retina. Proc Natl Acad Sci USA 74:5524-5528.

Thor S, Ericson J, Brännström T, Edlund T (1991) The homeodomain
LIM protein Isl-1 is expressed in subsets of neurons and endocrine cells in the adult rat. Neuron 7:881-889.

Tietje KM, Nathanson NM (1991) Embryonic chick heart expresses multiple muscarinic acetylcholine receptor subtypes: isolation and characterization of a gene encoding a novel $\mathrm{m} 2$ muscarinic acetylcholine receptor with high affinity for pirenzepine. J Biol Chem 266:17382-17387.

Tietje KM, Goldman PS, Nathanson NM (1990) Cloning and functional analysis of a gene encoding a novel muscarinic acetylcholine receptor expressed in chick heart and brain. J Biol Chem 265:2828-2834.

Townes-Anderson E, Vogt BA (1989) Distribution of muscarinic acetylcholine receptors on processes of isolated retinal cells. J Comp Neurol 290:369-383.

Wess J (1996) Molecular biology of muscarinic acetylcholine receptors. Crit Rev Neurobiol 10:69-99.

Willbold E, Reinicke M, Lance-Jones C, Lagenaur C, Lemmon V, Layer PG (1995) Müller glia stabilizes cell columns during retinal development: lateral cell migration but not neuropil growth is inhibited in mixed chick-quail retinospheroids. Eur J Neurosci 7:2277-2284.

Yamashita M, Fukuda Y (1993) Incurvation of early embryonic neural retina by acetylcholine through muscarinic receptors. Neurosci Lett 163:215-218. 